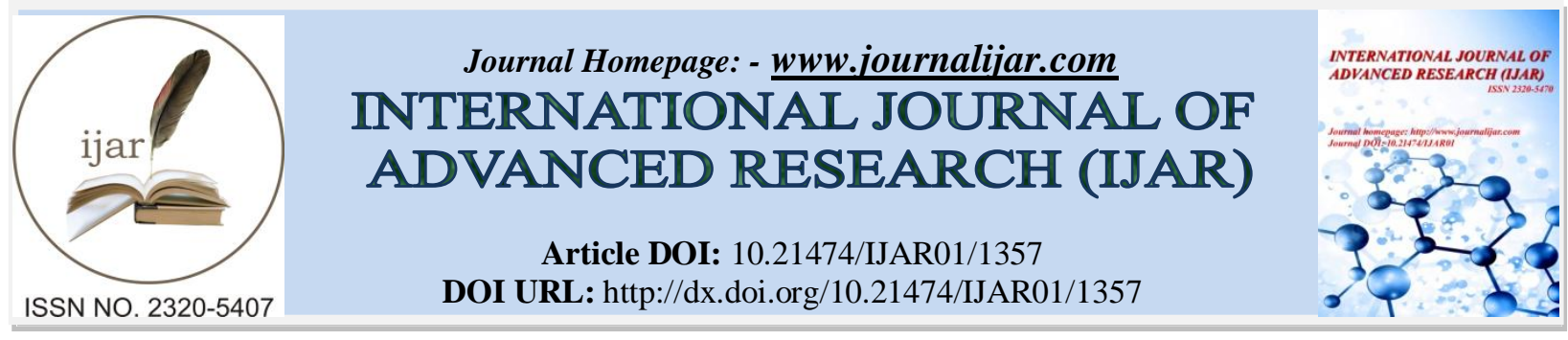

RESEARCH ARTICLE

\title{
BIOSORPTION OF MULTICOMPONENT REACTIVE SYNAZOL DYE FROM TEXTILE WASTEWATER BY PRETREATED BIOMASS OF ASPERGILLUS TERREUS.
}

${ }^{*}$ Kheiralla. Zeinab M. H. ${ }^{1}$, El-Mongy. T. M. ${ }^{2}$, Khalaf. M. A. ${ }^{2}$ and Khalil. M. F. A ${ }^{2}$.

1. Botany Department, Faculty of Women for Arts, Science and Education, Ain Shams University.

2. Microbiology Department, National Center for Radiation Research and Technology, P.O.Box-29, Nasr City, Cairo, Egypt.

\section{Manuscript Info}

Manuscript History

Received: 15 June 2016

Final Accepted: 22 July 2016

Published: August 2016

Key words:-

Biosorption; Reactive Synazol dye;

Textile wastewater, Aspergillus terreus;

Pretreatment.

\begin{abstract}
The potential of Aspergillus terreus fungus was investigated as a biosorbents for removal of reactive Synazol dye from its multicomponent textile wastewater. Pretreatment of fungal biomass with gamma radiation $(10 \mathrm{kGy})$ single and/or combined with others treatments increased the removal of dye compared with untreated biomass. The pretreatment biomass by gamma radiation ( $10 \mathrm{kGy})$ and heat autoclave for $30 \mathrm{~min}$. then soaked for $1 \mathrm{~h}$ in $10 \% \mathrm{H}_{2} \mathrm{SO}_{4}$, exhibited maximum dye removal at $\mathrm{pH} 3$, temperature $30{ }^{\circ} \mathrm{C}$ and $2 \mathrm{~g} \mathrm{~L}^{-1}(\mathrm{w} / \mathrm{v})$ biomass concentration after $6 \mathrm{~h}$ contact time under agitation rate 150 rpm.
\end{abstract}

Copy Right, IJAR, 2016,. All rights reserved.

\section{Introduction:-}

Synthetic dyes are widely used in many fields of advanced technology, e.g., in various kinds of the textile, paper, leather tanning, food processing, plastics, cosmetics, rubber, printing and dye manufacturing industries (Yagub et al., 2014). Dyes are classified as anionic (direct, acid and reactive dyes); cat ionic (basic dyes); and nonionic (disperse dyes). The textile industry plays an important role in the world economy as well as in our daily life, but at the same time, it consumes a large quantity of water and generates huge amount of wastewaters. Dye wastewater from textile industry is one of the most difficult industrial wastewaters to treat. The synthetic origin and complex aromatic structures of dyes make them stable and difficult to be biodegraded (Fewson, 1998). Such a wastewater is capable of causing hazardous environmental problems unless treated.

Up till now scientists have been trying to develop a single and economical method for the treatment of dyes in the textile wastewater but still it remains a big challenge (Espinosa-Ortiz, et al., 2016). There are various methods for the treatment of textile wastewater for the removal of dye. These broadly fall into three categories: Physical, Chemical and Biological. These methods have earlier been extensively reviewed (Robinson et al., 2001; Forgacs $\boldsymbol{e t}$ al., 2004 and Huang et al., 2016). The major disadvantage of physico-chemical methods has been largely due to the high cost, low efficiency, limited versatility, interference by other wastewater constituents and the handling of the waste generated. Microbial decolourization being cost-effective is receiving much attention for treatment of textile dye waste water (Stolz, 2001 and Zee and Villaverde, 2005).

Biological treatment may involve either aerobic or anaerobic degradation of the dyes by microorganisms (Kaushik and Malik, 2009). Due to the low biodegradability of dyes, conventional biological wastewater treatment systems

Corresponding Author:- Khalaf. M. A

Address:- Microbiology Department, National Center for Radiation Research and Technology, P.O.Box- 
are inefficient in treating dye wastewater (Fu and Viraraghavan, 2001). Adsorption has been shown to be the most promising option for all these non-biodegradable organics for the removal from aqueous streams (Aksu, 2005). Use of activated carbon has been found to be effective, but it is too expensive. Many studies have been undertaken to investigate the use of low-cost adsorbents such as peat, bentonite, steel-plant slag, fly ash, china clay, maize cob, wood shavings, and silica for color removal (Ramakrishna and Viraraghavan, 1997; Crini, 2006 and Gupta, 2009). However, these low-cost adsorbents have generally low adsorption capacities and require large amounts of adsorbents. Therefore, there is a need to find new, economical, easily available and highly effective adsorbents.

Alternatively, biosorption is one of the significant properties of both living and dead microorganisms (and their components) relevant for treatment of pollutants (Fomina and Gadd, 2014 and Asfaram et al., 2016). Biosorption is defined as binding of solutes to the biomass by processes which do not involve metabolic energy or transport, although such processes may occur simultaneously where live biomass is used. Therefore, it can occur in either living or dead biomass (Tobin et al., 1994 and Huang $\boldsymbol{e t}$ al., 2016). For a number of years, biosorption has been claimed as a promising biotechnology for pollutant removal and/or recovery from solution, due to its simplicity, high selectivity and efficiency, cost effectiveness and good removal performance (Wang and Chen, 2006; Fomina and Gadd, 2014 and Huang et al., 2016).

The special biomass properties of bacteria, yeasts, fungi and algae enable them to adsorb different kinds of pollutants from solutions (Aksu , 2005). The role of fungi in the treatment of wastewater has been extensively researched (Azmi et al., 1998; Coulibaly et al., 2003 and Espinosa-Ortiz, et al., 2016). Fungus has proved to be a suitable organism for the treatment of textile effluent and dye removal. Many genera of fungi have been employed for the dye decolourization either in living or dead form

The use of dead microbial cells in biosorption is more advantageous for water treatment in that dead organisms are not affected by toxic wastes, they do not require a continuous supply of nutrients and they can be regenerated and reused for many cycles. Dead cells may be stored or used for extended periods at room temperature without putrefaction occurring. Their operation is easy and their regeneration is simple. Moreover, dead cells have been shown to accumulate pollutants to the same or greater extent than growing or resting cells (Aksu, 2005; Chen et al., 2015 and Huang et al., 2016).

The major objective of this study was to investigate biosorption of reactive Synazol dye, Red and Yellow, commonly extensively used in local textile industry for coloring clothes in Egypt, onto dried non viable Aspergillus terreus biomass from multicomponent textile wastewater.

\section{Material and Methods:-}

\section{Fungal biomass preparation:-}

Aspergillus terreus (local strain) was gift from Industrial Microbiology Laboratory, National Center for Radiation Research and Technology (NCRRT), Nasr City, Cairo, Egypt. The fungus was cultured on Malt extract broth (MexB) in Erlenmeyer flasks $(250 \mathrm{~mL}$ ) each containing $100 \mathrm{~mL}$ of sterile MexB medium. The flasks (initial $\mathrm{pH}$ 5.6) were inoculated each with $1 \mathrm{~mL}$ spore suspension from A. terreus. The inoculated flasks were incubated for 6 days at $30^{\circ} \mathrm{C}$. After incubation biomasses were separated from the broth by filtration through Whatman No.1 paper and washed three times with distilled water. The harvested biomass was spread on Petri dish and dried at $60{ }^{\circ} \mathrm{C}$ in an oven for $48 \mathrm{~h}$, and then ground in a mortar and pestle, and stored in desiccators and termed as Aspergillus terreus dried biomass (ATDB).

\section{Textile wastewater (TWW)}

The TWW used in this study was obtained from a local textile factory located in Shobra El Khema, Cairo, Egypt. The samples were taken from the factory outlet. The dye in this effluent is a commercial Synazol reactive dye in multicomponent solutions (Red HF6BN, $1.25 \%$ and yellow HF2GR, $0.6 \%$ ). The main composition of this effluent is given in table-1.

\section{Spectrophotometeric analysis:-}

Scanning was performed between 400 and $800 \mathrm{~nm}$ by using UV/Visible spectrophotometer double beam PC (model: UVD-2950), to determine the maximum absorbance ( $\lambda \max$ ) wavelength of the diluted (1:10) untreated TWW. This dye wastewater showed $\lambda$ max value as $530 \mathrm{~nm}$. 


\section{Batch biosorption studies:-}

The experiments were conducted in $250 \mathrm{~mL}$ Erlenmeyer flasks containing $50 \mathrm{~mL}$ of this wastewater, without any dilution, and $0.1 \mathrm{~g}$ of pretreated and untreated biomasses. The batch experiments were performed under shaking $(150 \mathrm{rpm})$ at $30^{\circ} \mathrm{C}$ and initial $\mathrm{pH}$ value (5) for $2-10 \mathrm{~h}$. In the adsorption kinetic experiments samples were taken to measure the dye removal at predetermined time intervals.

To evaluate the effects of operation and environmental factors on the efficiency of dye removal, the batch biosorption experiments were carried out at different initial $\mathrm{pH}$ values (2 to 8), temperature range $\left(20\right.$ to $\left.40{ }^{\circ} \mathrm{C}\right)$ and biomass concentrations $\left(1\right.$ to $\left.4 \mathrm{~g} \mathrm{~L}^{-1}\right)$. The $\mathrm{pH}$ was adjusted by using $\mathrm{NaOH}$ and $\mathrm{HCl}$ solutions.

\section{Sample analysis:}

In all tests, the fungus biomass was removed from the treated solutions by centrifugation $(5000 \mathrm{rpm})$ for $5 \mathrm{~min}$ and the supernatants were collected and analyzed for residual dye concentrations.

The dye reduction percentage (\%) can be calculated as follows:

Reduction percentage $=\mathrm{C}_{i}-\mathrm{C}_{t} / \mathrm{C}_{i} \times 100$

Where $\mathrm{C}_{\mathrm{i}}$ and $\mathrm{C}_{\mathrm{t}}$ are the dye concentrations $\left(\mathrm{mg} \mathrm{L}^{-1}\right)$ in the initial TWW and after biosorption at time $t$, respectively.

Biosorption capacity $\mathbf{B C}=\left(\mathrm{C}_{i}-\mathrm{C}_{t}\right) \mathrm{x} \mathrm{V} / \mathrm{W}$

Where $\mathrm{BC}$ is the amount of dye biosorbed per gram of fungal biomass $\left(\mathrm{mg} \mathrm{g}^{-1}\right), \mathrm{V}$ is the TWW volume (L) and W is the amount of the biomass (g).

\section{Effect of some treatments on wet biomass activity:-}

The effect of some treatments on wet fungal biomass on $\mathrm{BC}$ before heat drying was investigation. The wet washed fungal biomasses were pretreated by different methods as follows:

*Autoclaved $5 \mathrm{~g}$ wet weight for different times (15-60 min) at $121{ }^{\circ} \mathrm{C}$ and 1 bar (ATDBt1).

*Irradiated $5 \mathrm{~g}$ wet weight with different doses of gamma radiation $(5-25 \mathrm{kGy}$ ) at ambient temperature (ATDBt2). Irradiation was carried out at the National Center for Radiation Research and Technology (NCRRT), using ${ }^{60} \mathrm{CO}$ gamma irradiation source of Indian Facility with a dose rate $\left(2.2 \mathrm{kGy} \mathrm{h}^{-1}\right)$ at the time of experiments.

* Boiled $5 \mathrm{~g}$ wet weight with $100 \mathrm{~mL}$ from different concentrations $(1,5,10$, and $15 \% \mathrm{v} / \mathrm{v})$ of each acid $(\mathrm{HCl}$, $\mathrm{H}_{2} \mathrm{SO}_{4}$ and $\mathrm{H}_{3} \mathrm{PO}_{4}$ ) for 60 min (ATDBt3, ATDBt4 and ATDBt5, respectively).

* Boiled $5 \mathrm{~g}$ wet weight with $100 \mathrm{ml}$ from different concentrations $(0.2,0.4,0.6$ and $0.8 \%)$ of each alkali $(\mathrm{NaOH}$, $\mathrm{NaHCO}_{3}$ and $\mathrm{CaCl}_{2}$ ) for 60 min (ATDBt6, ATDBt7 and ATDBt8, respectively).

Also, combination treatments between the best factor and others showed highly BC was carried out.

The biomass after each pretreatment was separated by filtration on Whatman no.1 paper, washed with sufficient amount of distilled water till the $\mathrm{pH}$ of the wash solution was in the range of 6.8-7.2 (natural range). After washing the biomass was dried at $60{ }^{\circ} \mathrm{C}$ for $48 \mathrm{~h}$ in drying oven, and then powdered and was stored in a desiccators as mentioned above. The biosorption activity of each treatment was carried out as mentioned before at optimizing conditions.

\section{Statistical analysis:-}

All the biosorption experiments in this study were conducted in triplicate and the average values \pm standard error (SE) were recorded. The data obtained were subjected to analysis of variance (T-test) according to (Spatz, 1993).

\section{Results and Discussion:-}

Effect of contact time:-

Biosorption data are most commonly represented by an equilibrium phase. So, contact time is one of the important parameters for successful deployment of the biosorbents for practical application and rapid sorption is among desirable parameters (Akar and Tunali, 2005). The results in table (2) showed that, a larger amount of reactive dye was removed in the first $2 \mathrm{~h}$ with reduction percent $23.33 \%$ and BC $215.66 \mathrm{mg} \mathrm{g}^{-1}$. Also, the data showed that, the $\mathrm{BC}$ was increased constantly with increasing contact time reaching to an equilibrium point of $312.66 \mathrm{mg} \mathrm{g}^{-1}$ in $6 \mathrm{~h}$. After this equilibrium time, there is a steady decrease observed on the BC. The BC of ethylene blue (MB) by dead fungal biomass, Aspergillus fumigatus increases with an increase in contact time and reaches a plateau at $90 \mathrm{~min}$, and the biosorption is very rapid in the first $30 \mathrm{~min}$ and then slowly declines with time until equilibrium (Abdallah 
and Taha, 2012). The initial rapid phase may be due to an increase in the number of vacant sites available at the initial stage (Belala et al., 2011). An increase observed on the BC with increasing contact time is due to availability of biosorption sites on the biomass surface. A decrease observed on the BC after equilibrium time could be related to the desorption of dye molecules from the biomass surfaces probably caused by repulsive forces between dye molecules at adjacent sites on the biomass surfaces (Gong et al., 2005). Therefore $6 \mathrm{~h}$ is fixed as the optimum contact time for the next experiments.

\section{Effect of biomass loading:-}

Table (3) shows the plot of dye remains concentration, \% reduction dye and dye uptake capacity (mg $\mathrm{g}^{-1}$ ) against biomass concentration. From the results in above table, it was observed that the amount of dye uptake increases with increasing biomass concentration. This increase of dye removal can be explained by the augment of the number of active sites of the fungal biomass preparations. On the other hand, the BC was decreased from $245.66 \mathrm{mg}^{-1}$ to $175.33 \mathrm{mg} \mathrm{g}^{-1}$ for an increase in biomass concentration from $1 \mathrm{~g}$ to $4 \mathrm{~g}$, with highest BC $313 \mathrm{mg} \mathrm{g}^{-1}$ at $2 \mathrm{~g}^{\text {biomass }}$ concentration (table 3 ). The decrease in biosorption capacity with increasing biosorbent concentration could be explained by not only unsaturation of biosorption sites through the adsorption reaction but also the particle interaction such as aggregation occurring at high biosorbent concentration and leading to decrease in total surface area (Shukla et al., 2002). Another reason could be due to the splitting effect of concentration gradient between dye molecules and biomass concentration causing a decrease in the amount of dye biosorbed onto unit weight of biomass (Malik, 2004).

\section{Effect of temperature:-}

Investigation of temperature effect on the biosorption of reactive dyes very important in the real application of biosorption as various textiles and other dye effluents are produced relatively high temperatures (FU and Viraraghavan, 2001). The results in table (4) showed that, the reduction \% of dye and $\mathrm{BC}$ were increased with increasing temperature from 15 to $30{ }^{\circ} \mathrm{C}$. The maximum value of reduction percent $34.40 \%$ and $\mathrm{BC}$ value $318.33 \mathrm{mg}$ $\mathrm{g}^{-1}$ were recorded at $25{ }^{\circ} \mathrm{C}$ with no significance difference with the results recorded at $30{ }^{\circ} \mathrm{C}$. Further increase in temperature from $30^{\circ} \mathrm{C}$ may alter the surface activity of biomass result in a decrease in dye up take value, indicating that this process is exothermic in nature. Xiong et al. (2010) noticed that, the adsorption capacity of nonviable $A$. niger biomass for C.I. Direct Blue 199 concentrations (C0) increased linearly with increasing C0 from 25 to $200 \mathrm{mg}$ $\mathrm{L}^{-1}$ at all the temperatures studied. Also, they observed that, the adsorption capacity increased from 18.34 to 29.96 $\mathrm{mg} \mathrm{g}^{-1}$ when the temperature rose from 25 to $35^{\circ} \mathrm{C}$ at a $\mathrm{C} 0$ of $400 \mathrm{mg} \mathrm{L}^{-1}$. This finding by the authors and our results implied that, the higher temperatures were responsible for an increase in active sites due to bond rupture (Dursun, 2006 and Xiong et al., 2010).

\section{Effect of initial pH:-}

The $\mathrm{pH}$ is an important parameter for biosorption studies and affects not only the biosorption capacity, but also the colour and solubility of dye solution (Waranusantigul et al., 2003). As seen in the table (5), as the pH was decreased, the biosorption of dye on the fungal biomass preparations increased with maximum dye removal percent $(52.12 \%)$ and $\mathrm{BC}\left(482.33 \mathrm{mg} \mathrm{g}^{-1}\right)$ at $\mathrm{pH}$ value 3 . On the other hand, the reduction of dye removal percent and $\mathrm{BC}$ of the biomass increased from $11.82 \%$ and $109.33 \mathrm{mg} \mathrm{g}^{-1}$ to $44.52 \%$ and $412 \mathrm{mg} \mathrm{g}^{-1}$ when the initial pH was decreased from 8 to 2. (table 5). This wide $\mathrm{pH}$ range could be an important advantage for the use of this system in natural conditions since almost all water resources have $\mathrm{pH}$ 6-8. The enhancement of uptake of dyes at acidic $\mathrm{pH}$ may be explained in terms of electrostatic interaction between the biomass and the dye particles. Since the dye molecule has net negative charges in aqueous solution, the positive sites of the fungal biomass are favorable for biosorption of the dye (Xiong et al., 2010). Acidic conditions cause a positive surface charge to develop on the adsorbent, resulting in higher adsorption of anionic species (Mane $\boldsymbol{e t}$ al., 2007). Under alkaline conditions, the decrease of $\mathrm{BC}$ could be due to the increasing number of negative charges distributed on the fungal biomass surface, which would result in electrostatic repulsion between the adsorbent and dye molecules. The present results are comparable with dye binding by other biosorbent materials. Fu and Viraraghavan (2002) reported that the effective initial $\mathrm{pH}$ was obtained at 6.0 and 4.0, for Acid Blue 29 and Basic Blue 9 dyes, respectively removal by inactivated fungal biomass of A. niger. Aksu and Tezer (2000) reported that the maximum Remazol Black B biosortion was obtained at pH 2.0 on the dried fungal biomass of Rhizopus arrhizus.

\section{Effect of autoclaving:-}

It is obviously seen from the results in table (6), that the treatment of the wet biomasses by autoclaving (ATDBt1) for $15,30,45$ and $60 \mathrm{~min}$ raised the uptake of the dye by $55.52 \%, 63.1 \%, 60.73 \%$ and $60.24 \%$, respectively. The 
results showed that, autoclaving for 30 min increased $\mathrm{BC}$ to $584 \mathrm{mg} \mathrm{g}^{-1}$ compared with $483 \mathrm{mg} \mathrm{g}^{-1}$ for untreated biomass (ATDB). (Abdallah and Taha, 2012) study the possibility of improving the biosorption of textile dye MB by dead fungal biomass, A. fumigates. They recorded that the fungal biomass treated with autoclaving (15 $\mathrm{min}$ ) resulted in higher removal of MB by 20\% compared with untreated biomass. Fu and Viraraghavan (2002) reported that autoclaving of the fungal biomass lead to increasing of the adsorption capacity of dyes than living biomass. They suggested after measuring the porosity and surface area of the fungal biomass that autoclaving could disrupt the biomass structure and expose the potential binding sites for dyes biosorption. This disruption of fungal biomass procures an increase in porosity of the particles and an increase of surface area and monolayer volume and thus exposes latent sites, consequently increasing the dye adsorption.

\section{Effect of gamma radiation:-}

Results in table (7) revealed that, the increase in dye removal percent concurrent with the increase of gamma irradiation dose. The maximum dye removal percent $(68.41 \%)$ with $\mathrm{BC}\left(632.66 \mathrm{mg} \mathrm{g}^{-1}\right)$ were recorded at dose 10 $\mathrm{kGy}$ compared with $51.94 \%$ and $480.33 \mathrm{mg} \mathrm{g}^{-1}$ for non irradiated biomass (ATDB). Also table (7) showed that, increase of irradiation dose above $10 \mathrm{kGy}$ lead to decrease in dye removal \% and $\mathrm{BC}$ compared with results obtained at $10 \mathrm{kGy}$. El-Batal et al. (2012) found that treatment of immobilized Aspergillus tamarii biomass with gamma irradiation dose $10 \mathrm{kGy}$ and 5\% formaldehyde increased the biosorption capability of dyes from textile wastewater. The improvement of the biosorptive capacity of the biomass treated by gamma radiation explained on the basis of formation of more electrostatic charges on the surface of the biomass which will change the overall surface charge and modification of binding sites thus the formation of electrostatic bonds between the biomass surface and the dye molecules (Zeroual et al., 2006). Also the disruption of fungal biomass by gamma radiation may cause an increase of surface area and monolayer volume and an increase in porosity of the particles and thus expose latent sites, consequently increasing the dye adsorption.

\section{Effect of acid treatment:-}

From the data presented in table (8) showed that all acids treatment increased percent of dye reduction and $\mathrm{BC}$ compared with untreated biomass. The maximum dye reduction $\%$ and $\mathrm{BC}$ were recorded by biomasses treated by $10 \%$ concentration of acids. The highest dye reduction percent $(64.64 \%)$ and $\mathrm{BC}\left(598 \mathrm{mg} \mathrm{g}^{-1}\right)$ were recorded by biomass treated by $10 \%$ concentration of $\mathrm{H}_{2} \mathrm{SO}_{4}$ (table 8). Other researchers, Fu and Viraraghavan (2002) and Arica and Bayramoglu (2007) observed that the acid treatment increasing the $\mathrm{BC}$ of A. niger and Lentinus sajorcaju native biomasses, for removal of congo red and reactive red-120 dyes, respectively, from aqueous solution. Acid treatment produces more active acidic surface groups such as carboxyl and lactone, resulting in an increase in the biosorption of reactive dye for the biosorbent (Khambhaty et al., 2012). In contrast the acidic treatment of A. fumigates with $\mathrm{H}_{2} \mathrm{SO}_{4} 0.1 \mathrm{M}$ decreased the $\mathrm{MB}$ biosorption percentage by $29 \%$ (from $42.5 \%$ to $13.5 \%$ ). This is due to the fact that $\mathrm{H}_{2} \mathrm{SO}_{4}$ pretreatment could change the negatively charged surface of the fungal biomass to positively charged and thus decrease the electrostatic attraction between fungal biomass and the cationic molecules of MB (Fu and Viraraghavan, 2001 and 2002).

\section{Effect of alkali treatment:-}

The data presented in table (9) showed that, $\mathrm{NaHCO}_{3}$ and $\mathrm{CaCl}_{2}$ pretreatment increased reduction $\%$ and $\mathrm{BC}$ of reactive dye from the TWW by $A$. terreus biomass. Pretreatment of wet fungal biomass by $\mathrm{NaOH}$ lead to decreased in reduction $\%$ of dye and $\mathrm{BC}$. In this study, $\mathrm{NaHCO}_{3}$ pretreatment at concentration $0.4 \%$ increased reduction $\%$ and $\mathrm{BC}$ for multicomponent reactive Synazol dye in TWW to the highest extent $\left(63.59 \%\right.$ and $588.16 \mathrm{mg} \mathrm{g}^{-1}$, respectively). The maximum increasing of $\mathrm{BC}$ by $\mathrm{NaHCO}_{3}$ pretreatment attributed to bicarbonate ion, $\mathrm{HCO}^{-3}$ can either provide protons or accept protons in water (Benefield and Randall, 1980). The protons could neutralize negative charges on the surface of fungal biomass and change the part of the negatively charged surface to positively charged. Meanwhile, changes in charge density could also affect ad sorption affinity for particular dyes. Fu and Viraraghavan (2002) found that $\mathrm{NaHCO}_{3}$ pretreatment increased biosorption capacity for Congo Red by A. niger biomass to the highest extent. An increase of adsorption efficiency by calcium saturation was demonstrated as a fact that the fungus biomass had a low affinity for $\mathrm{Ca}^{2+}$ ions, which made $\mathrm{Ca}^{2+}$ good activating counter ion which was easy to be replaced by dyes that formed more stable complexes (Aksu, 2005). Further increasing in $\mathrm{NaHCO}_{3}$ and $\mathrm{CaCl}_{2}$ concentration over $0.4 \%$ resulted in a significant decrease of dye uptake. This decrease of dye uptake may be attributed to the reduction of the number of binding sites for dye molecules due to bio- mass agglomeration (Patel and Suresh, 2008). On the other hand, the $\mathrm{NaOH}$ treated biomass had a low biosorp- tion capacity and this is because pretreatment by 
$\mathrm{NaOH}$ could generate anionic sites on the surface of fungal biomass (Gallagher et al., 1997) and thus increase repulsion between the negatively charged surface of the fungal biomass and the colored anions of reactive dye.

\section{Effect of combination pretreatments:-}

In this experiment various combination pretreatments between the superior treatment (gamma radiation, $10 \mathrm{kGy}$ ) and others showed highly biosorption capacities were studied. The gamma irradiated (10 kGy) wet biomasses were divided into 4 portions: first was treated by autoclaving (refered as ATDBt9), second was treated by autoclaving and $\mathrm{H}_{2} \mathrm{SO}_{4}\left(10 \% \mathrm{v} / \mathrm{v}\right.$, refered as ATDBt10), third was treated by autoclaving and $\mathrm{NaHCO}_{3}(0.4 \% \mathrm{v} / \mathrm{v}$, refered as ATDBt11). The forth portion was left as control (gamma treatment only, ATDBt2). The data presented in table (10) showed that there is a synergistic effect between the radiation dose at $10 \mathrm{kGy}$ and the autoclave and / or chemical treatments. The higher reduction percent of dye $81.18 \%$ and $\mathrm{BC} 751 \mathrm{mg} \mathrm{g}^{-1}$ were obtained by combination treatment of gamma radiation dose at $10 \mathrm{kGy}$ plus autoclaving and the chemical treatment with $10 \% \mathrm{H}_{2} \mathrm{SO}_{4}$ (ATDBt10). El-Batal et al. (2012) found that treatment of immobilized A. tamarii biomass with gamma irradiation dose $10 \mathrm{kGy}$ and $5 \%$ formaldehyde increased the biosorption capability of dyes from textile wastewater. The BC order of the combination fungal biomass preparation was observed as follows: $\gamma+$ autoclave $+\mathrm{H}_{2} \mathrm{SO}_{4}>\gamma+$ autoclave $+\mathrm{NaHCO}_{3}>\gamma+$ autoclave $>\gamma$ radiation (table 10). This increase in biosorption capacities for all combination treatments with gamma radiation can be attributed to crosslinking that made between the free active groups on the gamma irradiated cell wall by the other treatments leading to increase of the adsorption surface area compared with single treatment (gamma radiation).

In conclusion, the biosorption of multicomponent reactive Synazol dye from TWW on the treated and non treated, A.terreus dried biomass preparations was studied in a batch system with respect to contact time, temperature, medium $\mathrm{pH}$ and biomass loading. The results of the study clearly showed that physical and chemical surface modification methods can be used to maximize the dye removal efficiency of the fungal biomass. The medium $\mathrm{pH}$ and gamma radiation combination treatments played a significant role in affecting the biosorption capacities of fungal biomass preparations.

Table 1:- Composition of textile wastewater.

\begin{tabular}{|c|c|l|}
\hline Component & Type & Concentration \\
\hline Dyestuff & Synazol Red HF6BN & $1.25 \%$ \\
& Synazol Yellow HF2GR & $0.6 \%$ \\
\hline Salts & $\mathrm{NaCl}$ & $6.5 \%$ \\
& $\mathrm{Na}_{2} \mathrm{CO}_{3}$ & $0.2 \%$ \\
& $\mathrm{NaOH}$ & $0.4 \%$ \\
\hline Scouring & Folosan NOG & $0.09 \%$ \\
Fixation & Rew in ACP & $0.1 \%$ \\
Washoff & Exoline 1025 & $0.05 \%$ \\
\hline
\end{tabular}

Initial $\mathrm{pH}=10.6$

Table 2:- Effect of contact time on the biosorption of nonviable A. terreus biomass for multicomponent reactive Synazol dye from TWW.

\begin{tabular}{|l|l|l|l|}
\hline Contact time (h) & $\begin{array}{l}\text { Residual dye conc. }(\mathbf{m g} \\
\left.\mathbf{L}^{\mathbf{- 1}}\right)\end{array}$ & Reduction dye (\%) & $\begin{array}{l}\text { Biosorption capacity } \\
\left(\mathbf{B C}, \mathbf{~ m g ~ g}^{\mathbf{- 1}}\right)\end{array}$ \\
\hline $\mathbf{2}$ & $1418.33 \pm 9.52$ & $23.33 \pm 0.51$ & $215.66 \pm 4.91$ \\
\hline $\mathbf{4}$ & $1356.66 \pm 17.64$ & $26.66 \pm 0.95$ & $246.66 \pm 8.66$ \\
\hline $\mathbf{6}$ & $1224.66 \pm 12.44$ & $33.79 \pm 0.67$ & $312.66 \pm 6.38^{*}$ \\
\hline $\mathbf{8}$ & $1270.33 \pm 14.14$ & $31.34 \pm 0.74$ & $290 \pm 6.92$ \\
\hline $\mathbf{1 0}$ & $1341.33 \pm 13.87$ & $27.49 \pm 0.74$ & $254.33 \pm 6.93$ \\
\hline $\mathbf{1 2}$ & $1406.66 \pm 13.34$ & $23.95 \pm 0.72$ & $221.66 \pm 6.38$ \\
\hline
\end{tabular}

Control dye conc.: $1850 \mathrm{mg} \mathrm{L}^{-1}$; Biomass loading: $2 \mathrm{~g} \mathrm{~L}^{-1}$; $\mathrm{pH}: 5$; Temp.: $30{ }^{\circ} \mathrm{C}$; Agitation rate: $150 \mathrm{rpm}$. Values are mean of 3 average $\pm \mathrm{SE}$; * Significant from all values $(\mathrm{P}<0.01)$

Table 3:- Effect of nonviable A. terreus biomass loading on the biosorption of multicomponent reactive Synazol dye from TWW. 


\begin{tabular}{|l|l|l|l|}
\hline Biomass loading (g) & $\begin{array}{l}\text { Residual dye conc. }(\mathbf{m g} \\
\left.\mathbf{L}^{-\mathbf{1}}\right)\end{array}$ & Reduction dye (\%) & $\begin{array}{l}\text { Biosorption capacity } \\
\left(\mathbf{B C}, \mathbf{~ m g ~ g}^{-1}\right)\end{array}$ \\
\hline $\mathbf{1}$ & $1604 \pm 15.55$ & $13.27 \pm 0.83$ & $245.66 \pm 15.55$ \\
\hline $\mathbf{2}$ & $1224.33 \pm 10.98$ & $33.81 \pm 0.59$ & $313 \pm 5.50^{*}$ \\
\hline $\mathbf{3}$ & $1106.66 \pm 17.62$ & $40.17 \pm 0.95$ & $247.66 \pm 6.06$ \\
\hline $\mathbf{4}$ & $1149.33 \pm 18.04$ & $37.87 \pm 0.97$ & $175.33 \pm 4.66$ \\
\hline
\end{tabular}

Control dye conc.: $1850 \mathrm{mg} \mathrm{L}^{-1}$; pH: 5; Temp.: $30{ }^{\circ} \mathrm{C}$; Agitation rate: $150 \mathrm{rpm}$; Contact time: $6 \mathrm{~h}$. Values are mean of 3 average $\pm \mathrm{SE}$; $*$ Significant from all values $(\mathrm{P}<0.01)$

Table 4:- Effect of temperature on the biosorption of nonviable A. terreus biomass for multicomponent reactive Synazol dye from TWW.

\begin{tabular}{|c|c|c|c|}
\hline Temp. $\left({ }^{\circ} \mathrm{C}\right)$ & $\begin{array}{l}\text { Residual dye conc. (mg } \\
\mathrm{L}^{-1} \text { ) }\end{array}$ & Reduction dye (\%) & $\begin{array}{ll}\text { Biosorption } & \text { capacity } \\
\left(\text { BC, } \mathbf{~ m g ~ g ~}^{-1}\right) & \end{array}$ \\
\hline 15 & $1345.66 \pm 18.20$ & $27.25 \pm 0.98$ & $252 \pm 8.96$ \\
\hline 20 & $1273.33 \pm 18.47$ & $31.16 \pm 0.99$ & $288 \pm 9.23$ \\
\hline 25 & $1213.33 \pm 14.43$ & $34.40 \pm 0.77$ & $318.33 \pm 7.21^{*}$ \\
\hline 30 & $1229.33 \pm 15.03$ & $33.54 \pm 0.81$ & $310.33 \pm 7.51^{*}$ \\
\hline 35 & $1283.66 \pm 17.70$ & $30.61 \pm 0.95$ & $283.33 \pm 8.98$ \\
\hline 40 & $1386 \pm 16.28$ & $25.07 \pm 0.88$ & $232 \pm 8.14$ \\
\hline
\end{tabular}

Control dye conc.: $1850 \mathrm{mg} \mathrm{L}^{-1}$; Biomass loading: $2 \mathrm{~g} \mathrm{~L}^{-1}$; $\mathrm{pH}$ : 5; Agitation rate: $150 \mathrm{rpm}$; Contact time: $6 \mathrm{~h}$. Values are mean of 3 average \pm SE; * Significant from all values $(\mathrm{P}<0.01)$

Table 5:- Effect of $\mathrm{pH}$ on the biosorption of nonviable A. terreus biomass for multicomponent reactive Synazol dye from TWW.

\begin{tabular}{|l|l|l|l|}
\hline $\mathbf{p H}$ & $\begin{array}{l}\text { Residual dye conc. } \mathbf{( m g} \\
\mathbf{L}^{-\mathbf{1}} \mathbf{)}\end{array}$ & Reduction dye (\%) & $\begin{array}{l}\text { Biosorption capacity } \\
\left(\mathbf{B C}, \mathbf{~ m g ~ g}^{-1}\right)\end{array}$ \\
\hline $\mathbf{2}$ & $1026.33 \pm 12.70$ & $44.52 \pm 0.69$ & $412 \pm 6.35$ \\
\hline $\mathbf{3}$ & $885.66 \pm 11.89$ & $52.12 \pm 0.64$ & $482.33 \pm 5.81^{*}$ \\
\hline $\mathbf{4}$ & $1065.66 \pm 11.97$ & $42.39 \pm 0.64$ & $392.33 \pm 6.11$ \\
\hline $\mathbf{5}$ & $1221 \pm 10.21$ & $33.99 \pm 0.55$ & $314.33 \pm 4.97$ \\
\hline $\mathbf{6}$ & $1371.66 \pm 14.88$ & $25.85 \pm 0.80$ & $239.33 \pm 7.50$ \\
\hline $\mathbf{7}$ & $1434.33 \pm 15.01$ & $22.46 \pm 0.81$ & $208 \pm 7.23$ \\
\hline $\mathbf{8}$ & $1631 \pm 15.04$ & $11.82 \pm 0.81$ & $109.33 \pm 7.51$ \\
\hline
\end{tabular}

Control dye conc.: $1850 \mathrm{mg} \mathrm{L}^{-1}$; Biomass loading: $2 \mathrm{~g} \mathrm{~L}^{-1}$; Temp.: $30^{\circ} \mathrm{C}$; Agitation rate: $150 \mathrm{rpm}$; Contact time:

$6 \mathrm{~h}$. Values are mean of 3 average \pm SE; * Significant from all values $(\mathrm{P}<0.01)$

Table 6:- Biosorption capacities of nonviable A. terreus dried biomass (ATDB) and autoclaved-treated biomass (ATDBt1) for multicomponent reactive Synazol dye from TWW.

\begin{tabular}{|l|l|l|l|}
\hline Time of autoclaving (min) & $\begin{array}{l}\text { Residual dye conc. }(\mathbf{m g} \\
\left.\mathbf{L}^{-\mathbf{1}}\right)\end{array}$ & Reduction dye (\%) & $\begin{array}{l}\text { Biosorption capacity } \\
\left(\mathbf{B C}, \mathbf{~ m g ~ g}^{-1}\right)\end{array}$ \\
\hline $\mathbf{1 5}$ & $822.66 \pm 12.19$ & $55.52 \pm 0.65$ & $502.66 \pm 4.63$ \\
\hline $\mathbf{3 0}$ & $681 \pm 7$ & $63.1 \pm 0.37$ & $584 \pm 4.61^{*}$ \\
\hline $\mathbf{4 5}$ & $726.33 \pm 12.14$ & $60.73 \pm 0.67$ & $562.33 \pm 5.48$ \\
\hline $\mathbf{6 0}$ & $735.33 \pm 8.11$ & $60.24 \pm 0.44$ & $567.33 \pm 6.35$ \\
\hline Control (ATDB) & $886.33 \pm 9.83$ & $52.08 \pm 0.53$ & $483 \pm 6.35$ \\
\hline
\end{tabular}

Control dye conc.: $1850 \mathrm{mg} \mathrm{L}^{-1}$; Biomass loading: $2 \mathrm{~g} \mathrm{~L}^{-1}$; pH: 3 ; Temp. $30^{\circ} \mathrm{C}$; Agitation rate: $150 \mathrm{rpm}$.; Contact time: $6 \mathrm{~h}$. Values are mean of 3 average $\pm \mathrm{SE} ; *$ Significant from all values $(\mathrm{P}<0.01)$ 
Table 7:- Biosorption capacities of nonviable A. terreus dried biomass (ATDB) and gamma radiation-treated biomass (ATDBt2) for multicomponent reactive Synazol dye from TWW.

\begin{tabular}{|l|l|l|l|}
\hline $\begin{array}{l}\text { Gamma Radiation dose } \\
(\mathbf{k G y})\end{array}$ & $\begin{array}{l}\text { Residual dye conc. }(\mathbf{m g} \\
\left.\mathbf{L}^{-\mathbf{1}}\right)\end{array}$ & Reduction dye (\%) & $\begin{array}{l}\text { Biosorption capacity } \\
\left(\mathbf{B C}, \mathbf{~ m g ~ g}^{-\mathbf{1}}\right)\end{array}$ \\
\hline $\mathbf{5}$ & $724 \pm 6.42$ & $60.91 \pm 0.38$ & $563 \pm 3.21$ \\
\hline $\mathbf{1 0}$ & $582.33 \pm 5.36$ & $68.41 \pm 0.37$ & $632.66 \pm 3.48^{*}$ \\
\hline $\mathbf{1 5}$ & $607.33 \pm 9.82$ & $67.16 \pm 0.52$ & $621.33 \pm 4.91$ \\
\hline $\mathbf{2 0}$ & $643.33 \pm 12.41$ & $65.22 \pm 0.66$ & $603.33 \pm 6.35$ \\
\hline $\mathbf{2 5}$ & $721.33 \pm 11.56$ & $61 \pm 0.62$ & $564.33 \pm 5.78$ \\
\hline Control (ATDB) & $889 \pm 14.73$ & $51.94 \pm 0.79$ & $480.33 \pm 7.51$ \\
\hline
\end{tabular}

Control dye conc.: $1850 \mathrm{mg} \mathrm{L}^{-1}$; Biomass loading: $2 \mathrm{~g} \mathrm{~L}^{-1}$; $\mathrm{pH}: 3$; Temp.: $30{ }^{\circ} \mathrm{C}$; Agitation rate: $150 \mathrm{rpm}$;

Contact time: $6 \mathrm{~h}$. Values are mean of 3 average $\pm \mathrm{SE}$; * Significant from all values $(\mathrm{P}<0.01)$

Table 8:- Biosorption capacities of nonviable A. terreus dried biomass (ATDB) and acid-treated biomass for multicomponent reactive Synazol dye from TWW.

\begin{tabular}{|c|c|c|c|c|}
\hline $\begin{array}{l}\text { Type } \\
\text { acids }\end{array}$ & $\begin{array}{l}\text { Concentration } \\
(\% \mathrm{v} / \mathrm{v})\end{array}$ & $\begin{array}{l}\text { Residual dye conc. } \\
\left(\mathrm{mg} \mathrm{L}^{-1}\right)\end{array}$ & $\begin{array}{l}\text { Reduction dye } \\
(\%)\end{array}$ & $\begin{array}{ll}\text { Biosorption } & \text { capacity } \\
\left(\mathrm{BC}, \mathrm{mg} \mathrm{g}^{-1}\right) & \\
\end{array}$ \\
\hline \multirow{4}{*}{$\mathrm{HCl}$} & 1 & $817 \pm 7.23$ & $55.91 \pm 0.40$ & $516.5 \pm 3.61$ \\
\hline & 5 & $725.66 \pm 7.53$ & $60.77 \pm 0.40$ & $562 \pm 3.76$ \\
\hline & 10 & $682.66 \pm 6.93$ & $63.1 \pm 0.39$ & $583.5 \pm 3.46^{*}$ \\
\hline & 15 & $714 \pm 3.46$ & $61.41 \pm 0.18$ & $568 \pm 3.46$ \\
\hline \multirow{4}{*}{$\mathrm{H}_{2} \mathrm{SO}_{4}$} & 1 & $811 \pm 3.78$ & $56.17 \pm 0.20$ & $519.5 \pm 3.78$ \\
\hline & 5 & $692.66 \pm 6.93$ & $62.60 \pm 0.34$ & $578.66 \pm 3.46$ \\
\hline & 10 & $654 \pm 6.08$ & $64.64 \pm 0.32$ & $598 \pm 3.04^{*}$ \\
\hline & 15 & $672.33 \pm 11.67$ & $63.70 \pm 0.32$ & $588.83 \pm 3.37$ \\
\hline \multirow{4}{*}{$\mathrm{H}_{3} \mathrm{PO}_{4}$} & 1 & $835.66 \pm 6.48$ & $54.93 \pm 0.38$ & $507.5 \pm 3.5$ \\
\hline & 5 & $753.33 \pm 8.11$ & $59.30 \pm 0.43$ & $548.33 \pm 4.05$ \\
\hline & 10 & $712.33 \pm 5.23$ & $61.50 \pm 0.37$ & $568.33 \pm 3.08^{*}$ \\
\hline & 15 & $736.33 \pm 8.37$ & $60.24 \pm 0.48$ & $556.83 \pm 4.18$ \\
\hline $\begin{array}{l}\text { Control } \\
\text { (ATDB) }\end{array}$ & & $882.33 \pm 6.17$ & $52.31 \pm 0.32$ & $483.83 \pm 3.61$ \\
\hline
\end{tabular}

Control dye conc.: $1850 \mathrm{mg} \mathrm{L}^{-1}$; Biomass loading: $2 \mathrm{~g} \mathrm{~L}^{-1}$; $\mathrm{pH}$ : 3; Temp.: $30{ }^{\circ} \mathrm{C}$; Agitation rate: $150 \mathrm{rpm}$;

Contact time: $6 \mathrm{~h}$. Values are mean of 3 average $\pm \mathrm{SE}$; * Significant from all values $(\mathrm{P}<0.01)$

Table 9:- Biosorption capacities of nonviable A. terreus dried biomass (ATDB) and alkali -treated biomass for multicomponent reactive Synazol dye from TWW.

\begin{tabular}{|c|c|c|c|c|}
\hline Type of alkali & $\begin{array}{l}\text { Concentration } \\
(\% \mathrm{w} / \mathrm{v})\end{array}$ & $\begin{array}{l}\text { Residual dye conc. } \\
\left(\mathrm{mg} \mathrm{L}^{-1}\right)\end{array}$ & $\begin{array}{l}\text { Reduction dye } \\
(\%)\end{array}$ & $\begin{array}{ll}\text { Biosorption } & \text { capacity } \\
\left(\mathrm{BC}, \mathrm{mg} \mathrm{g}^{-1}\right) & \end{array}$ \\
\hline \multirow{4}{*}{$\mathrm{NaOH}$} & 0.2 & $914 \pm 6.08$ & $50.59 \pm 0.33$ & $468 \pm 3.04$ \\
\hline & 0.4 & $939 \pm 7.23$ & $47.63 \pm 1.28$ & $455.5 \pm 3.61$ \\
\hline & 0.6 & $974.33 \pm 8.45$ & $47.37 \pm 0.46$ & $437.83 \pm 4.22$ \\
\hline & 0.8 & $981.66 \pm 6.38$ & $47 \pm 0.34$ & $434.16 \pm 3.19$ \\
\hline \multirow{4}{*}{$\mathrm{NaHCO}_{3}$} & 0.2 & $777.33 \pm 7.05$ & $57.98 \pm 0.37$ & $536.33 \pm 3.52$ \\
\hline & 0.4 & $673.66 \pm 6.38$ & $63.59 \pm 0.34$ & $588.16 \pm 3.19^{\prime \prime}$ \\
\hline & 0.6 & $693.66 \pm 5.54$ & $62.6 \pm 0.28$ & $578.16 \pm 2.77$ \\
\hline & 0.8 & $712.33 \pm 6.38$ & $61.57 \pm 0.31$ & $568.83 \pm 3.19$ \\
\hline \multirow{4}{*}{$\mathrm{CaCl}_{2}$} & 0.2 & $805.66 \pm 6.93$ & $56.47 \pm 0.37$ & $522.16 \pm 3.46$ \\
\hline & 0.4 & $695 \pm 8.96$ & $62.45 \pm 0.47$ & $577.5 \pm 4.48^{*}$ \\
\hline & 0.6 & $715 \pm 6.42$ & $61.43 \pm 0.38$ & $567.5 \pm 3.21$ \\
\hline & 0.8 & $724 \pm 6.42$ & $60.91 \pm 0.38$ & $563 \pm 3.21$ \\
\hline $\begin{array}{l}\text { Control } \\
\text { (ATDB) }\end{array}$ & & $884.33 \pm 6.35$ & $52.21 \pm 0.34$ & $482.83 \pm 3.17$ \\
\hline
\end{tabular}

Control dye conc.: $1850 \mathrm{mg} \mathrm{L}^{-1}$; Biomass loading: $2 \mathrm{~g} \mathrm{~L}^{-1}$; pH: 3; Temp.: $30^{\circ} \mathrm{C}$; Agitation rate: $150 \mathrm{rpm}$;

Contact time: $6 \mathrm{~h}$. Values are mean of 3 average $\pm \mathrm{SE}$; * Significant from all values $(\mathrm{P}<0.01)$ 
Table 10:- Effect of different combination pretreatments on the biosorption of nonviable A. terreus biomass for multicomponent reactive Synazol dye from TWW.

\begin{tabular}{|c|c|c|c|}
\hline Combination pretreatments & $\begin{array}{l}\text { Residual dye conc. } \\
\left(\mathrm{mg} \mathrm{L}^{-1}\right)\end{array}$ & $\begin{array}{l}\text { Reduction dye } \\
(\%)\end{array}$ & $\begin{array}{l}\text { Biosorption capacity } \\
\left(\mathrm{BC}, \mathrm{mg} \mathrm{g}^{-1}\right)\end{array}$ \\
\hline$\gamma+$ autoclave (ATDBt9) & $465.66 \pm 9.24$ & $74.82 \pm 0.49$ & $692 \pm 4.61$ \\
\hline$\gamma+$ autoclave $+\mathrm{H}_{2} \mathrm{SO}_{4}(\mathrm{ATDBt10})$ & $348 \pm 9.81$ & $81.18 \pm 0.52$ & $751 \pm 5.19^{*}$ \\
\hline$\gamma+$ autoclave $+\mathrm{NaHCO}_{3}(\mathrm{ATDBt11})$ & $403.33 \pm 8.11$ & $78.19 \pm 0.43$ & $723.33 \pm 4.05$ \\
\hline Control $-\gamma$ only (ATDBt2) & $581.33 \pm 10.71$ & $68.57 \pm 0.57$ & $634 \pm 5.50$ \\
\hline
\end{tabular}

Control dye conc.: $1850 \mathrm{mg} \mathrm{L}^{-1}$; Biomass loading: $2 \mathrm{~g} \mathrm{~L}^{-1}$; pH: 3; Temp.: $30{ }^{\circ} \mathrm{C}$; Agitation rate: $150 \mathrm{rpm}$;

Contact time: $6 \mathrm{~h}$. Values are mean of 3 average $\pm \mathrm{SE}$; * Significant from all values $(\mathrm{P}<0.01)$

\section{References:-}

1. Abdallah, R. and Taha, S. (2012). Biosorption of methylene blue from aqueous solution by nonviable Aspergillus fumigatus. Chemical Engineering Journal. 195-196: 69-76.

2. Akar, T. and Tunali, S. (2005). Biosorption performance of Botrytis cinerea fungal byproducts for removal of $\mathrm{Cd}(\mathrm{II})$ and $\mathrm{Cu}$ (II) ions from aqueous solutions. Miner. Engin. 18: 1099-1109.

3. Aksu, Z. (2005). Application of biosorption for the removal of organic pollutants: a review. Process Biochem. 40: 997-1026.

4. Aksu, Z. and Tezer, S., ( 2000). Equilibrium and kinetic modelling of biosorption of Remazol Black B by Rhizopus arrhizus in a batch system: effect of temperature. Process Biochem. 36, 431-439.

5. Arica, M. and Bayramoglu, G. (2007). Biosorption of Reactive Red 120 dye from aqueous solution by native and modified fungus biomass preparations of Lentinus sajorcaju. J. Hazard. Mater. 149, 499-507

6. Asfaram, A.; Ghaedi, M.; Ghezelbash, G.R.; Dil, E.A.; Tyagi, I.; Agarwal, S. and Gupta, V.K. (2016). Biosorption of malachite green by novel biosorbent Yarrowia lipolytica isf7: Application of response surface methodology. Journal Molecular Liquids, 214: 249-258

7. Azmi, W.; Sani, R.K. and Banerjee, U.C. (1998). Biodegradation of triphenylmethane dyes. Enzyme Microb. Technol. 22:185-191.

8. Benefield, L.D. and Randall, C.W. (1980). Inorganic materials. Biological Process Design for Wastewater Treatment. Prentice-Hall, Englewood Cliffs, NJ, p. 81.

9. Belala, Z.; Jeguirim, M.; Belhachemi, M.; Addoun, F. and Trouvé, G. (2011). Biosorption of basic dye from aqueous solutions by date stones and palm-trees waste: kinetic, equilibrium and thermodynamic studies, Desalination, 271: 80-87.

10. Chen, S.H. and Ting, A.S.Y. (2015). Biosorption and biodegradation potential of triphenylmethane dyes by newly discovered Penicillium simplicissimum isolated from indoor wastewater sample. International Biodeterioration \& Biodegradation, 103: 1-7

11. Coulibaly, L.; Gourene, G. and Agathos, N.S. (2003).Utilization of fungi for biotreatment of raw wastewaters. Afr. J. Biotechnol.,2:620-30.

12. Crini, G., (2006). Non-conventional low-cost adsorbents for dye removal: a review. Bioresource Technol. 97: 1061-1085.

13. Dursun, A.Y. (2006). A comparative study on determination of the equilibrium, kinetic and thermodynamic parameters of biosorption of copper (II) and lead (II) ions onto pretreated Aspergillus niger, Biochem. Eng. J. 28: 187-195.

14. El-Batal, A.I.; Hashem, A.M.; Hassan, M.S. and Helal, A.H. (2012). Removal of dyes from textile wastewater using treated Aspergillus tamari biomass in batch and column reactor. World Appl. Sci. J. 19: 13051310.

15. Espinosa-Ortiz, E.J.; Rene, E.R.; Pakshirajan, K.; van Hullebusch, E.D. and Lens, P.N.L. (2016). Fungal pelleted reactors in wastewater treatment: Applications and perspectives. Chemical Engineering Journal, 283: 553-571

16. Fewson, C.A. (1998). Biodegradation of xenobiotic and other persistent compounds: the causes of recalcitrance. Trends Biotechnol. 6: 148-153.

17. Fomina, M. and Gadd, G.M. (2014). Biosorption: current perspectives on concept, definition and application. Bioresource Technology, 160: 3-14

18. Forgacs, E.; Cserhati, T. and Oros, G. (2004). Removal of synthetic dyes from wastewaters: a review. Environ. Int. 30: 953-971 
19. Fu, Y. and Viraraghavan, T. (2001). Fungal decolorization of dye wastewaters: a review. Bioresource Technol. 79: 251-262.

20. Fu, Y. and Viraraghavan, T. (2002). Dye biosorption sites in Aspergillus niger. Bioresource Technol. 82: 139145.

21. Gallagher, K.A.; Healy, M.G. and Allen, S.J. (1997). Biosorption of synthetic dye and metal ions from aqueous effluents using fungal biomass. In: Wise, D.L. (Ed.). Global Environmental Biotechnology. UK: Elsevier; pp. 27-50.

22. Gong, R.; Ding, Y.; Liu, H.; Chen, Q. and Liu, Z. (2005). Lead biosorption and desorption by intact and pretreated spirulina maxima biomass, Chemosphere, 58: 125-130.

23. Gupta, V (2009). Application of low-cost adsorbents for dye removal-a review. J. Environ. Manage. 90:2313-2342.

24. Huang, J.; Liu, D.; Lu, J.; Wang, H.; Wei, X. and Liu, J. (2016). Biosorption of reactive black 5 by modified Aspergillus versicolor biomass: Kinetics, capacity and mechanism studies. Colloids and Surfaces A: Physicochemical and Engineering Aspects, 492: 242-248

25. Kaushik, P. and Malik, A. (2009). Fungal dye decolourization: recent advances and future potential. Environ. Int. 35: 127-141.

26. Khambhaty, Y.; Mody, K. and Basha, S. (2012). Efficient removal of Brilliant Blue G (BBG) from aqueous solutions by marine Aspergillus wentii: Kinetics, equilibrium and process design. Ecological Engineering, 41: 74- 83.

27. Malik, A. (2004). Metal bioremediation through growing cells. Environ. Int. 30: 261- 278.

28. Mane, V.S.; Mall, I.D. and Srivastava, V.C. (2007). Kinetic and equilibrium isotherm studies for the adsorptive removal of Brilliant Green dye from aqueous solution by rice husk ash, J. Environ. Manag. 84: 390-400.

29. Patel, R. and Suresh, S. (2008). Kinetic and equilibrium studies on the biosorption of reactive black 5 dye by Aspergillus foetidus, Bioresour. Technol. 99: 51-58.

30. Ramakrishna, K. and Viraraghavan, T. (1997). Dye removal using low cost adsorbents. Water Sci. Technol. 36: 189-196.

31. Robinson, T.; McMullan, G.; Marchant, R. and Nigam, P. (2001). Remediation of dyes in textile effluent: a critical review on current treatment technologies with a proposed alternative 2001. Bioresource Technol. 77:247-255.

32. Shukla, A.; Zhang, Y.; Dubey, P.; Margrave, J.L. and Shukla, S.S. (2002). The role of sawdust in the removal of unwanted materials from water, J. Hazard. Mater. B 95: 137-152.

33. Spatz, C. (1993): Basic Statistics. $5^{\text {th }}$ ed., Brooks / Cole Publ. Co., California, Inc. USA.

34. Stolz A. (2001). Basic and applied aspects in the microbial degradation of azo dyes. Appl Microbiol Biotechnol. 56:69-80.

35. Tobin, J.M.; White, C. and Gadd, G.M. (1994). Metal accumulation by fungi: applications in environment biotechnology. J Industrial Microb. 13:126-130.

36. Wang, J. and Chen, C., (2006). Biosorption of heavy metals by Saccharomyces cerevisiae: a review. Biotechnol. Adv. 24: 427-451.

37. Xiong, X-J.; Menga, X-J. and Zheng, T-L. (2010). Biosorption of C.I. Direct Blue 199 from aqueous solution by nonviable Aspergillus niger. J. Hazardous Materials 175: 241-246

38. Yagub, M.T.; Sen, T.K.; Afroze, S. and Ang, H.M. (2014). Dye and its removal from aqueous solution by adsorption: A review. Adv. Colloid Interface Sci. 209: 172-184

39. Zee, F.P. and Villaverde, S. (2005). Combined anaerobic-aerobic treatment of azodyes - a short review of bioreactor studies. Water Res. 39:1425-1440.

40. Zeroul, Y.; Kim, B.S.; Kim, C.S.; Blaghen, M. and Lee, K.M. (2006). Biosrption of Bromophenol blue from aqueous solutions by Rhizoups stolonifer biomass. Water, Air \& Soil pollution, 177:135-146. 